\title{
Fluxes of dissolved mineral elements through a forest ecosystem submitted to extremely high atmospheric pollution inputs (Czech Republic)
}

\author{
E Dambrine 1, V Kinkor 2, J Jehlicka 2, D Gelhaye 1 \\ 1 INRA-CRF, Champenoux, 54280 Seichamps, France; \\ 2 Geological Institute, Malostranske 19, 11821 Prague, Czech Republic
}

(Received 3 September 1992; accepted 20 December 1992)

\begin{abstract}
Summary - Fluxes of dissolved mineral elements have been monitored in a declining spruce stand in northern Bohemia. This area is subjected to very high atmospheric pollution. Mean annual throughfall $\mathrm{pH}$ was 3.15 and monthly mean values as low as 2.6 were recorded. Measurements show deposition values per ha and per year as high as $150 \mathrm{~kg} \mathrm{~S}, 60 \mathrm{~kg} \mathrm{Ca}$ and $12 \mathrm{~kg} \mathrm{Al}$ as well as a proton input $>5 \mathrm{keq} / \mathrm{ha} / \mathrm{yr} \mathrm{H} \mathrm{H}^{+}$. Part of the input was immobilized in the litter layer and the remaining acid load was buffered by Al release in the mineral horizons. High nutrient inputs may explain why no mineral deficiencies have been detected, although tree mortality is extremely high in this area.
\end{abstract}

atmospheric pollution / acidification / forest soils / forest decline / Czech Republic

Résumé - Flux d'éléments minéraux dans un écosystème forestier hyper-pollué du nord de la Bohème (Réblique tchèque). Les flux d'éléments minéraux en solution dans un peuplement d'épicéa dépérissant du nord de la Bohème ont été mesurés au cours de l'année 1989. Cette région subit une effroyable pollution atmosphérique due à l'exploitation minière et à la combustion de lignite riche en soufre et en cendres dans un bassin industriel voisin ainsi que dans plusieurs centres industriels du sud de l'Allemagne (ex-RDA). Nous avons mesuré des dépôts atmosphériques sous le couvert forestier considérables : respectivement $150 \mathrm{~kg}$ de $S, 60 \mathrm{~kg}$ de $\mathrm{Ca}, 46 \mathrm{~kg}$ de N, $12 \mathrm{~kg}$ d'Al par ha et par an. Ces valeurs, environ 5 fois supérieures à celles couramment mesurées dans les peuplements vosgiens, sont attribuables aux émissions importantes de cendres de combustion dont la dissolution neutralise une partie du dépôt acide. Néanmoins, le dépôt atmosphérique acide dépasse $5 \mathrm{keq} \mathrm{H}^{+} / \mathrm{ha} / \mathrm{an}$ avec des $\mathrm{pH}$ moyens mensuels dans les pluies sous couvert descendant à 2,6. Curieusement, la vague de mortalité qui dévore ces peuplements (40 000 ha de forêts étaient déclarés morts en 1987), ne s'accompagne pas de symptômes de carences minérales visibles (Mg, Ca ou K) du type de celles généralement observées en France et en Allemagne dans les peuplements d'épicéas dépérissants. Les considérables apports atmosphériques de nutriments mesurés pourraient expliquer ce phénomène. La cause directe des mortalités est attribuée aux effets directs de la pollution atmosphérique (acidité et teneurs en $\mathrm{SO}_{2}$ ) accentués par les phénomènes climatiques (fortes gelées). En ce sens, les dépérissements observés diffèrent fortement de ceux étudiés en France. Les conséquences à long terme, dans cette région, des dépôts acides et de métaux 
lourds sur les propriétés des sols, la qualité des eaux, mais aussi sur la santé humaine, sont telles, que linterruption des émissions est extrêmement souhaitable.

pollution atmosphérique / acidification / sols forestiers / dépérissement / République tchèque

\section{INTRODUCTION}

During the eighties, the existence of large areas of forest damaged by atmospheric pollution in the East European regions was described by the western media and dramatic pictures of this ecological disaster were shown in the press. At the same time, symptoms of a new type of disease, rapidly called forest decline (Waldsterben) were observed in many forested areas in West European countries. Such a coincidence, and the fact that forest damage in the East was indisputably caused by atmospheric pollution led many foresters and scientists to consider that atmospheric pollution was the main cause of forest decline in the West European forests.

Collaboration between Czech and French scientists was initiated in 1988 in order to analyse the differences between the causes of forest decline in East and West European countries.

The influence of high pollutant inputs on hydro-geochemical cycles at the catchment level had been studied in northern Bohemia for several years by the Geological Institute of Prague (Paces, 1985; Moldan and Dvorakova, 1987). However, although the chemical properties of the soils had been analysed on a broad scale by foresters (Materna, 1989), no data were available on dynamic budgets at the soil scale. The following study was designed to assess the chemical changes occurring within the soil of a living spruce stand under the influence of such high inputs. It presents the results of continuous monitor- ing of mineral fluxes within this ecosystem over a 1-yr period.

\section{SITE GEOGRAPHY AND ECOLOGY (KUBELKA, 1987)}

The Krusne Hory mountains in northern Bohemia consist of Hercynian crystalline rocks. They are formed by a plateau which slopes gradually towards the north of the German border. From the edge and towards the south, this range drops steeply into the Krusne Hory piedmont basin. The forests are composed of beech (Fagus sylvatica) in the piedmont and spruce, whose development above $400 \mathrm{~m}$ has been favoured by foresters. The soils vary from an acid oligotrophic brown earth to podzolic types on the slopes, and peaty soils develop on the flat surfaces of the plateau.

This range is subjected to extremely high levels of atmospheric pollution due to the intensive mining and burning of brown coal in the basin. Brown coal is composed of $26-44 \%$ ashes and $0.5-3 \%$ sulphur. Winds blowing from the south-east carry gaseous and solid pollution to the higher altitudes where they meet cold air masses coming from the north east. Fogs enriched with pollutants develop in the area of contact, ie between $600-800 \mathrm{~m}$ above sea level. This zone represents the site of the heaviest emission-induced damage. Obvious symptoms of decline consist essentially of reddening and needle losses. No large-scale discolouration linked to mineral deficiencies has been reported in this area (Pfans and Beyschlag, 1993). 
Until 1930, the forest in this area was considered healthy. In 1950, after the first survey of forest health, 30000 ha were considered to be endangered. Forest dieback has increased gradually since 1977 . Mortality has increased significantly, presumably under the cumulative influence of increased emissions, prolonged temperature inversions and abrupt climatic changes. In $1986,>65 \%$ of the forest in this area was considered seriously damaged and $16 \%$ was dead.

Mechanised techniques including scraping of the humus (considered to be too acid), drainage, liming and fertilisation, and plantation with pollution-resistant species are currently being applied in order to reafforest this area.

\section{MATERIALS AND METHODS}

The forest stand was located on a gentle northwest slope facing the East German border near the village of Nacetin, $10 \mathrm{~km}$ north of Chomutov. It was chosen because defoliation was limited, and soils were known not to be limed in this area; the stand is at an altitude of $780 \mathrm{~m}$. Mean precipitation is $\approx 800 \mathrm{~mm}$ per year and mean temperature is $6^{\circ} \mathrm{C}$. In comparison with these average values, the period studied (1988-1989) was relatively dry, especially during the winter. The trees were 70-90-yr old spruce with a mean height of $\approx 25 \mathrm{~m}$. Defoliation was noticeable and was estimated to be $\approx 30-40 \%$. The needles were sometimes red in colour, generally attributed to the direct effects of $\mathrm{SO}_{2}$, or to interaction between $\mathrm{SO}_{2}$ and frost. The density of the stand, which was considerably reduced by felling of dead trees during the last decade, was currently 440 trees/ha in the area studied. This recent opening of the stand permitted strong growth of the ground vegetation which covered the entire soil surface except at the foot of the trees, where large amounts of litter accumulated, composed of 5-50 $\mathrm{m}^{2}$ patches of Vaccinum myrtillus and dense herbaceous species (Deschampsia flexuosa, Calamagrostis $\mathrm{sp}$ ). Four pits were dug in the soil, and after their main morphological characters and root density had been described, they were sampled. Several samples of each horizon were bulked and a homogenised sample of each horizon was analysed. Exchangeable base cations and acidity were determined after $1 \mathrm{M} \mathrm{KCl}$ extraction. CEC was calculated as the sum of the exchangeable base cations and acidity. Total sulphur was determined by $X$-ray fluorescence.

In the autumn of 1988, throughfall collectors and soil solution samplers were set up. Each throughfall collector consisted of a polyethylene guttering $10 \mathrm{~cm}$ deep with an area of $1800 \mathrm{~cm}^{2}$. One was set up in the immediate vicinity of a tree trunk and 2 others within the space between 2 trees. One bulk precipation collector was set up in June 1989 in a clearing, a few hundred $m$ from the stand.

Zero tension lysimeters were inserted into the front of several soil pits: in the $F$ horizon and at $-10 \mathrm{~cm}$ ( $E$ horizon), $-30 \mathrm{~cm}$ (Bs), $-70 \mathrm{~cm}$ $(B C 1),-100 \mathrm{~cm}(B C 2)$. Lysimeters in the humus were narrow $(\varnothing=3 \mathrm{~cm})$ open polyethylene pipes $50 \mathrm{~cm}$ in length. Nine of them were inserted in the transition zone between the $\mathrm{F}$ and $\mathrm{H}$ horizon of a Vaccinium myrtillus zone, with 9 others in a grass area. Lysimeters in the mineral soil consisted of $50 \mathrm{~cm} \times 40 \mathrm{~cm}$ polyethylene plates. Three lysimeters per sampling depth were carefully inserted by pushing them into the soil parallel to the terrain slope with a hydraulic device. Nylon tubes were connected to the lysimeter exit and led along a trench to a second pit located a few $m$ dowslope in which collecting barrels were set up. The pits in which lysimeters were inserted were refilled afterwards with the soil taking into account the natural horizon order. In order to collect water during periods of slow drainage, a set of 3 teflon cups (Prenart type) were set up at $-100 \mathrm{~cm}$. A tension of 500 mbar was applied once a month via a manual pump.

Solutions were sampled monthly and bulked for each depth except for the organic layer for which the solutions originating from the Vaccinium and grass areas were analysed separately. Solutions were filtered through $0.45-\mu \mathrm{m}$ micropore filters under air pressure and analysed by standard methods in the Geological Survey laboratory. The mineral element budget was calculated by multiplying the volume weighted mean annual values of concentration by either the measured annual amount of throughfall, or a calculated amount of drainage water. Taking into account the poor crown conditions of the 
trees, the low density of the stand, and the drought which occurred during the summer, we assumed that the transpiration of the forest stand was equal to $100 \mathrm{~mm} / \mathrm{yr}$. This value is = $50 \%$ of that derived from direct transpiration measurements on defoliated mature spruce stands in rather similar climatic conditions (Dambrine et al, 1992). The ground vegetation was assumed to take up $50 \mathrm{~mm} / \mathrm{yr}$. Uptake of water was distributed within the soil assuming that it was proportional to the observed root density. Thus, we related $20 \%$ of the water uptake to the humus layer, $30 \%$ to the $0-10 \mathrm{~cm}$ layer, $30 \%$ to the $10-30 \mathrm{~cm}$ layer and the remainder to the deeper horizons.

\section{RESULTS AND DISCUSSION}

\section{Soil chemical characteristics}

The soil is a podzolic type soil developed on a coarse gneissic saprolite. Table 1 presents the main soil analytical characteristics. $\mathrm{pH}$ is extremely low except in the $\mathrm{H}$ layer. In spite of these low $\mathrm{pH}$ values, base saturation values are in the same range as those measured in numerous studies dealing with far less polluted areas (Kinkor, 1988; Probst et al, 1990; Feger et al, 1991). Of interest is the relatively high base saturation of the $\mathrm{H}$ horizon, which denotes a significant accumulation of these elements. This might reflect the dissolution of soluble salts during $\mathrm{KCl}$ extraction. Tottal sulphur concentration is high in the organic layer and decreases markedly with depth.

\section{Mineral element dynamic}

Figure 1 presents the average volume weighted mean concentrations of anions and cations in solutions throughout their pathway from open land precipitation to deep drainage.

\section{Bulk precipitation}

Bulk precipitation is strongly acid (table II): $\mathrm{pH}$ of monthly samples varies between 3.8 and 4.4 , which is within the range of the values measured in industrialised countries (Semb and Dovland, 1987; Cape and

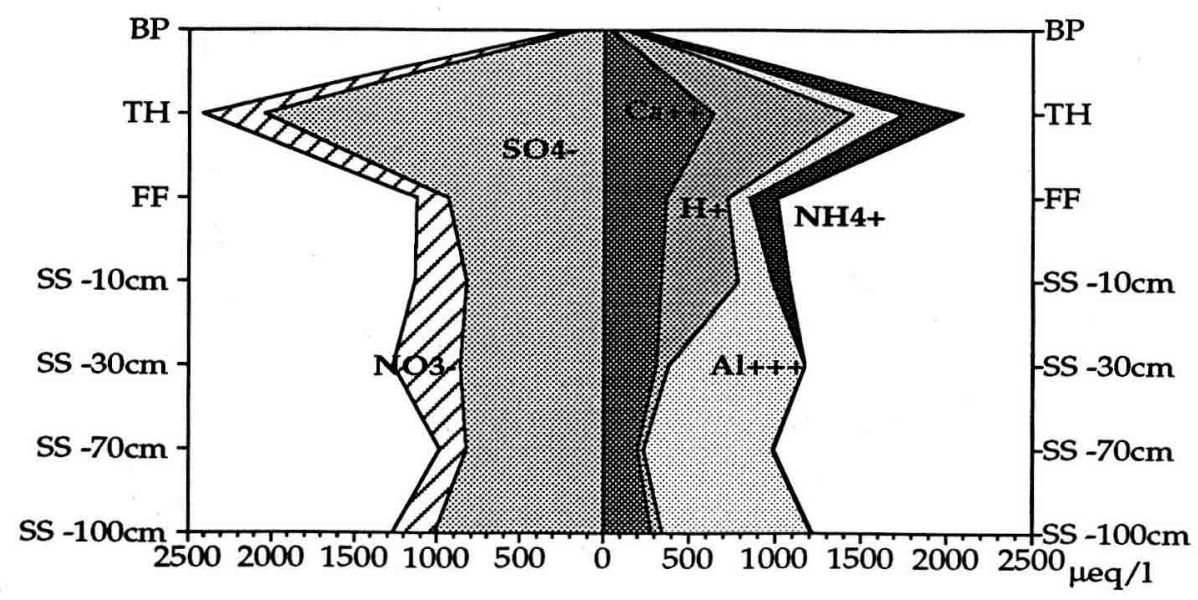

Fig 1. Variations of mean annual concentrations ( $\mu \mathrm{eq} / \mathrm{l})$ in solution throughout a spruce ecosystem. BP: bulk precipitation; TH: throughfall; FF: forest floor; SS: soil solutions at varying depths. 


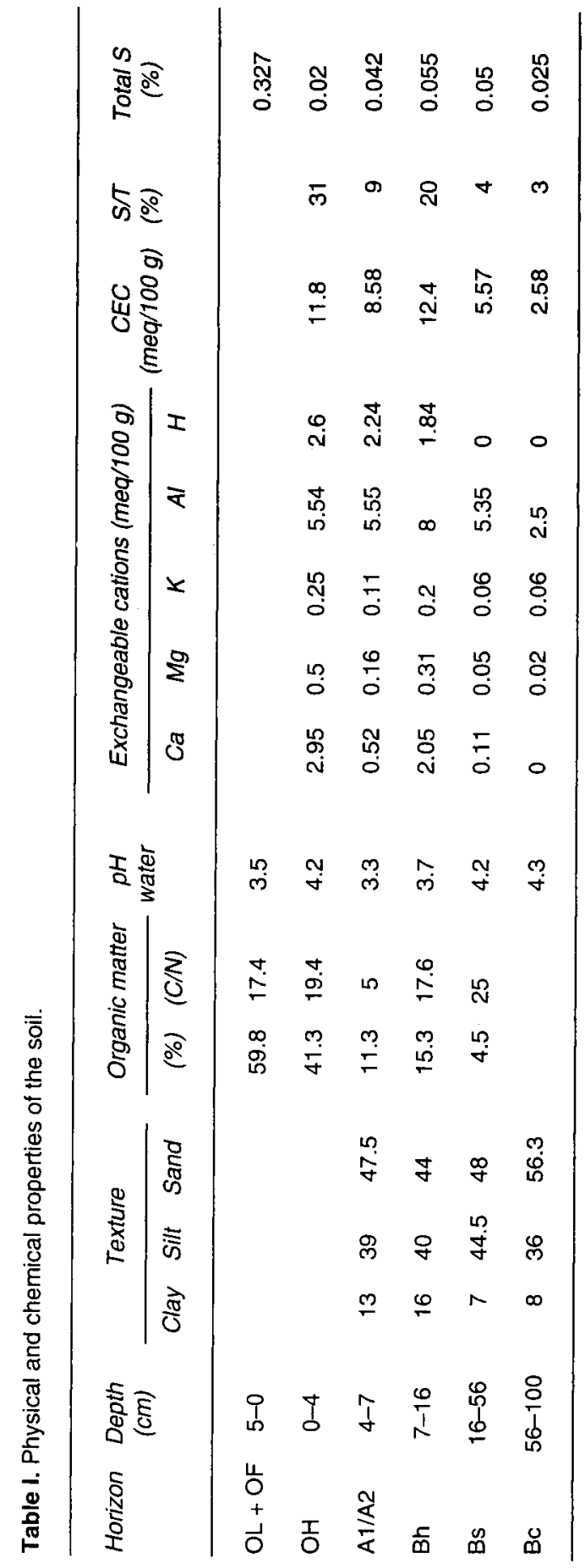


Table II. Mean annual concentrations $(\mu \mathrm{eq} / \mathrm{l})$ and concentration ratio of throughfall to bulk precipitation.

$\begin{array}{llllllllllllll}\begin{array}{c}\text { Concentration } \\ (\mu e q /)\end{array} & H & M n & K & \mathrm{Ca} & \mathrm{Mg} & \mathrm{Na} & \mathrm{Al} & \mathrm{Fe} & \mathrm{Zn} & \mathrm{NH}_{4} & \mathrm{SO}_{4} & \mathrm{~F} & \mathrm{Cl}\end{array}$

$\begin{array}{lrrrrrrrrrrrrr}\text { Bulk precipitation } & 77.4 & 0.4 & 3.8 & 43.7 & 9.0 & 7.0 & 15.9 & 2.3 & 3.9 & 42.3 & 143.7 & 4.6 & 10.8 \\ \text { Throughfall } & 813.7 & 14.7 & 189.1 & 639.3 & 148.1 & 127.5 & 284.1 & 42.3 & 4.7 & 355.1 & 2048.6 & 78.2 & 180.9 \\ \text { TH/BP } & 10.5 & 36.8 & 49.8 & 14.6 & 16.5 & 18.2 & 17.9 & 18.4 & 0.6 & 8.4 & 14.3 & 17.0 & 16.8\end{array}$

Fowler, 1987). However, most concentrations are relatively high compared with other data from less polluted areas. In contrast, concentrations appear rather low compared with those measured by Paces (1985) in a catchment located on the southern slope of the massit, facing the brown coal power station. The limited number of bulk precipitation samples collected in this study does not allow any further comparison to be made.

\section{Canopy}

When passing through the canopy, concentrations increase considerably, far more than the concentration effect due to interception: as a mean, conductivity is multiplied by 9 . $\mathrm{pH}$ drops to a mean value of 3.15 with extreme monthly values as low as 2.6 (March 1989). The homogeneity of the ratios between throughfall and open land precipitation concentrations, except for $\mathrm{K}$ and $\mathrm{Mn}$ which are known to be leached from the canopy, show that this increase is derived mainly from the deposition of gas and airborne ash, originating from the combustion of brown coal (table II). It is worth noting the very high concentrations of basic cations as $\mathrm{Ca}$, but also of $\mathrm{Fe}$ and $\mathrm{Al}$, which are more typical of acid soil solutions than throughfall. Assuming that most of these elements come from wind-blown ash, one can calculate that al- most $50 \%$ of the acidity associated with the dissolution of sulphuric acid is buffered by the dissolution of these cations (Hodgson et al, 1982).

\section{Forest floor}

A considerable decrease of concentrations for most of the elements occurs within the humus layer. Sulphate is divided by a factor of 2.2 , chloride by 1.6 , and calcium by 1.5 (table III). The reduction is greater under the grass area compared to the area with Vaccinium. Because both areas are located in similar positions in relation to the trees, this difference is probably derived from the effect of the ground vegetation itself rather than from the spatial variability of deposition.

\section{Mineral soil}

Concentrations remain rather stable from the humus layer to the $E$ horizon, except for silica which increases markedly and for the nitrogen compounds: $\mathrm{NH}_{4}$ decreases as $\mathrm{Al}$ and $\mathrm{H}^{+}$increase, parallel to $\mathrm{NO}_{3}$. This change can be attributed to nitrification of deposited $\mathrm{NH}_{4}$. In spite of the strong acidity of the solutions, the input of $\mathrm{Ca}$ maintains a rather high $\mathrm{Ca}$ :Al ratio (2.5).

The main change occurs within the upper Bs horizon where $\mathrm{Al}$ is released 


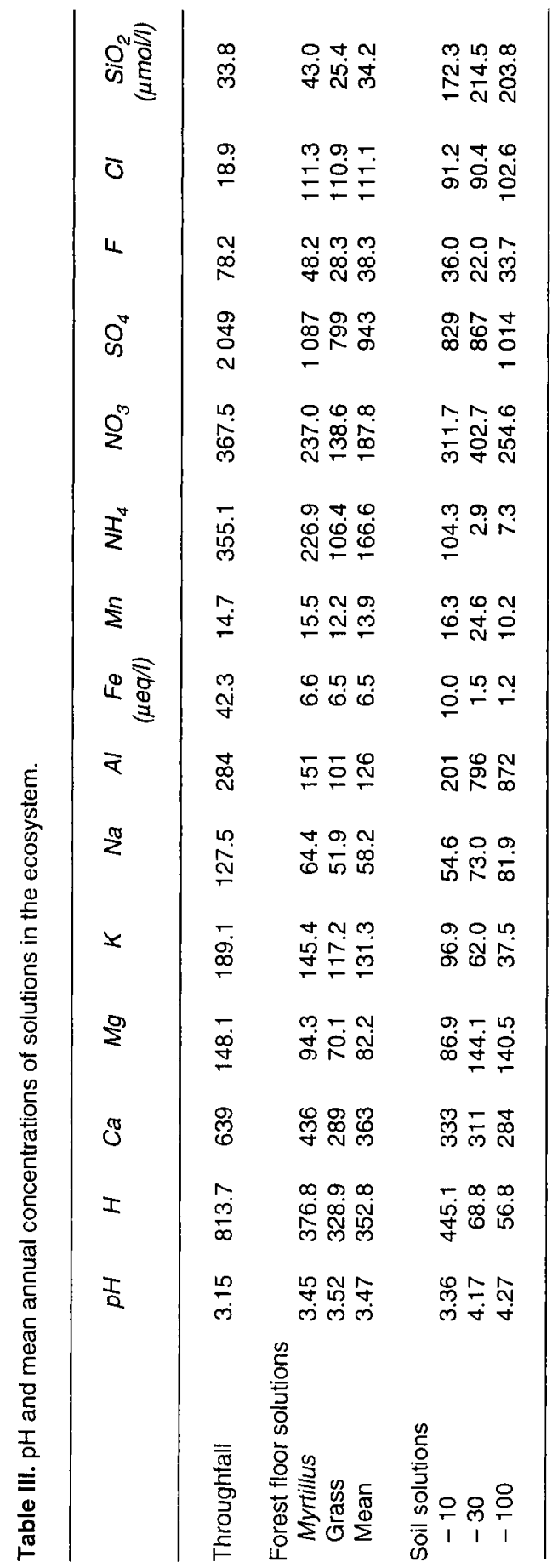


while protons are consumed (fig 1). Figure 2 shows a clear relationship between $\mathrm{Al}^{3+}$ and $\mathrm{SO}_{4}^{2-}$ ions in solution at different depths. This leads to high Al concentrations and to a rather low Ca:Al ratio (0.6 at $-30 \mathrm{~cm} ; 0.5$ at $-100 \mathrm{~cm})$. However, it should be noted that those ratios are not particularly low compared with those measured in various healthy or declining spruce stands (Bredemeier et al, 1990; Probst et al, 1990). This is due to the high concentration of basic cations linked to the large inputs of these elements. Neither the basic cations nor $\mathrm{Si}$ concentration increase significantly in solution from -10 to $-100 \mathrm{~cm}$. Thus the release of such elements by weathering may be very low, in spite of the strong acidifying conditions. Al release may be derived from the dissolution of amorphous $\mathrm{Al}$ compounds, as shown by Mulder et al (1989).

The following aspects of changes in concentrations throughout the ecosystem are relatively original as compared with other studies: 1) the extremely high concentrations of sulphur but also of $\mathrm{Ca}$ and
$\mathrm{Mg}, \mathrm{Al}$ and heavy metals in throughfall, associated with atmospheric inputs; 2) the strong decrease in concentrations from throughfall to the litter layer. This decrease may be attributed to different causes: a) the measurements of throughfall might slightly overestimate the deposition because collectors were placed in an area where the canopy was slightly denser than in the neighbouring area where the lysimeters were located. However, the overestimation of the deposition should not exceed $20 \%$. Moreover, the measured amount of throughfall is relatively low compared with the open land precipitation, taking into account the poor crown conditions; b) the ground vegetation, which recently has developed very rapidly takes up a large amount of elements. This is likely when comparing the first set of lysimeters in the forest floor which was placed under a large area of Vaccinium with the second set under dense grasses; c) elements are temporarily immobilised in the litter layer because of the relatively dry conditions. None of these explanations is fully satisfactory be-

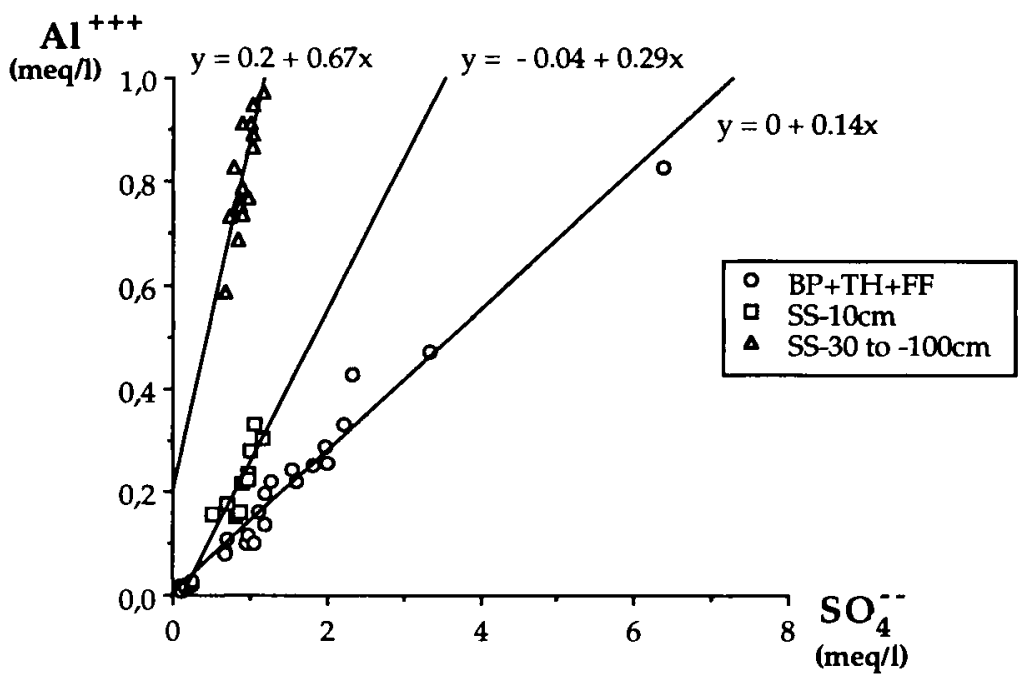

Fig 2. Relations between the ionic concentrations of $\mathrm{SO}_{4}^{2-}$ and $\mathrm{Al}^{3+}(\mathrm{meq} / \mathrm{l})$ in the solutions sampled monthly at different levels of the ecosystem. 
cause of the very substantial reduction in concentration of all the elements including chloride, but a combined effect is likely; 3 ) in spite of the rather low $\mathrm{C}: \mathrm{N}$ ratio of the forest floor, solutions passing through this layer do not show the peak in basic cations and nitrogen concentrations commonly found in other studies and generally attributed to organic matter mineralisation. This might be due to a low mineralisation associated with the drastic deposition chemistry (Lettl, 1990) and/or to the development of ground vegetation.

\section{Mineral element budgets}

Table IV shows the budget of major ions from open land deposition to deep seepage water. The depositions of sulphur, calcium and magnesium in throughfall amount respectively to 150,58 and $8 \mathrm{~kg} /$ ha/yr which are among the highest values reported in the literature (Hauhs et al, 1990). The amounts of $\mathrm{Ca}, \mathrm{Mg}$ and $\mathrm{Al}$ in throughfall buffer $\approx 50 \%$ of the acidity associated with the sulphur input. These basic cation inputs might explain why the trees do not suffer from $\mathrm{Ca}$ or $\mathrm{Mg}$ deficiencies. However, even if we neglect the proton load neutralised by base cation ex- change in the canopy, the acidity input associated with free protons, $\mathrm{Al}$ and $\mathrm{Fe}$ ions remains extremely high $(5.2 \mathrm{keq} / \mathrm{ha} / \mathrm{yr})$. All element fluxes are reduced when passing through the forest floor. One should bear in mind that this horizon shows a relatively high base saturation in spite of its low $\mathrm{pH}$. In fact, whatever the artefacts due to the short period of study, this accumulation of basic cations in the humus may be linked to the flux reduction measured in this layer. It is interesting to note that the sulphur flux is that which is reduced the most drastically. Even if we use chloride as an index, the importance of the reduction within the humus layer is limited, but remains. Sulphur might accumulate in the humus (David and Mitchell, 1987; Vannier, 1992), or be lost as a gas (Goldan et al, 1987). The strong smell in the air in this area could be partly derived from these emissions. A similar difference between $S$ input and output was noticed by Kinkor (1988) for a catchment located $\approx 10 \mathrm{~km}$ south of this stand. Thus, this sulphur reduction process in the humus layer appears possible although unexplained. Although mineral drainage is reduced compared to the input, the leaching of acidity as free protons and $\mathrm{Al}^{3+}$ amounts to $2.85 \mathrm{keq} / \mathrm{ha} / \mathrm{yr}$ which is buffered at present in the regolith.

Table IV. Fluxes of dissolved mineral elements throughout the ecosystem $(\mathrm{kg} / \mathrm{ha} / \mathrm{yr})$.

\begin{tabular}{|c|c|c|c|c|c|c|c|c|c|}
\hline & $\begin{array}{l}\text { Water } \\
(\mathrm{mm})\end{array}$ & $H$ & $\mathrm{Ca}$ & $M g$ & $\begin{array}{c}A l \\
(\mathrm{~kg} / \mathrm{ha} / \mathrm{yr})\end{array}$ & $Z n$ & $N$ & $s$ & $\mathrm{Cl}$ \\
\hline Throughfall & 457 & 3.7 & 58.4 & 8.1 & 11.7 & 0.7 & 46.1 & 149.8 & 29.3 \\
\hline \multicolumn{10}{|l|}{ Soil solutions } \\
\hline Forest floor & 427 & 1.5 & 31.0 & 4.2 & 4.8 & 0.5 & 21.2 & 64.4 & 16.8 \\
\hline-10 & 382 & 1.7 & 25.4 & 4.0 & 6.9 & 0.4 & 22.3 & 50.7 & 12.4 \\
\hline-30 & 337 & 0.2 & 21.0 & 5.8 & 24.1 & 0.5 & 19.1 & 46.7 & 10.8 \\
\hline-100 & 307 & 0.2 & 17.4 & 5.2 & 24.1 & 0.3 & 11.2 & 49.8 & 11.2 \\
\hline
\end{tabular}




\section{CONCLUSION}

In spite of the short period covered by this study, several interesting features have been observed and confirm previous independent investigations. The stand studied receives extremely high amounts of a large number of chemical elements which are acidifying compounds, nutrients and heavy metals. Because of the presence of nutrients in this cocktail of pollutants, the acidifying effect of such an input into the soil is probably not the driving force of forest damage in this area (Pfans and Beyschlag, 1992). In fact, although proton deposition is very high, basic cation input seems high enough to prevent basic cation deficiencies, at least for the moment. Because the main buffering process within the soil is the dissolution of aluminium compounds, acidity is transferred down to the regolith. Thus, the risks of groundwater pollution are very serious.

The absence of a release of nitrogen and base cations in the soil solutions of the forest floor suggest a low rate of decomposition, which might be linked to the acidity of the deposition or to its heavy metal content. In fact, little is known about the deposition rates of heavy metals in this area, in particular beryllium and arsenic which are present in brown coal clays (Kubiznakova, 1987) and may have disastrous effects on living organisms.

The extremely high sulphur input does not seem to be transferred entirely to the deeper soil horizons, nor to the streams. Accumulation of sulphur in the humus layer and/or gaseous sulphur compound emissions are possible mechanisms which could contribute to this process.

Because very large forest areas (several hundred thousand ha) in Czechoslovakia, Eastern Germany and Poland have been and are still damaged by this type of pollution, a great reduction of the emissions is urgently required.

\section{REFERENCES}

Bredenmeir M, Matzner E, Ulrich B (1990) Internal and external proton load to forest soils in northern Germany. J Environ Qual 19, 469477

Cape JN, Fowler D (1987) Rainfall acidity in northern Britain-exploring the data. In: Proc Int Symp Acidic Precipitation Muskoka (Martin H, ed) D Reidel, Dordrecht, 239-244

Dambrine E, Carisey N, Pollier B, Girard S, Granier A, Lu P, Biron P (1992) Dynamique des éléments minéraux dans la sève xylémique d'épicéa de 30 ans. Ann Sci For 5 (in press)

David MB, Mitchell MJ (1987) Transformation of organic and inorganic sulphur: importance to sulfate flux in an Adirondack forest soil. JAPCA 37, 39-44

Feger KH, Zöttl HW, Brahmer G (1991) Assessment of the ecological effects of forest fertilization using an experimental watershed approach. Fertil Res 27, 49-61

Goldan PD, Kuster WC, Albritton DL, Fehsenfeld FC (1987) The measurements of natural sulfur emissions from soils and vegetation: three sites in the Eastern United States revisited. J Atmos Chem 5, 439-467

Hauhs M, Rost Siebert K, Raben G, Paces T, Vigerust B (1990) Summary of European data. In: The Role of Nitrogen in the Acidification of Soils and Surface Waters (Malanchuk and Nisson, eds) Nordic Council of Ministers, 500-536

Hodgson L, Dyer D, Brown DA (1982) Neutralisation and dissolution of high-calcium fly ash. J Environ Qual 11, 93-98

Kinkor W (1987) Acidifcation of two small basins in the Krusne Hory mountains. In: Extended Abstr, Geomon Congr May 1987 (Moldan and Paces, eds) Prague, 204-206

Kinkor W (1988) Influence of acid rain on chemical properties of soils in the Bohemian massif (Czechoslovakia). In: Int Rep Agric. Univ Wageningen, The Netherland, p 35

Kubelka $L$ (1987) Forestry in the Krusne Hory mountains. In: Excursion Guide, GEOMON Workshop, May 1987 (Paces and Moldan, eds) Prague, 19-26

Kubiznakova $J$ (1987) Behaviour of beryllium in the Sokolov district. In: Extended Abstr GEO- 
MON Congr, May 1987 (Moldan and Paces, eds) Prague, 188-190

Lettl A (1990) Influence of industrial $\mathrm{SO}_{2}$ immissions on microorganisms of forest soils. Ekologia 9, 315-330

Materna $J$ (1989) Air pollution and forestry in Czechoslovakia. Environ Monit Assess 12, 227-235

Moldan B, Dvorakova M (1987) Atmospheric deposition into small drainage basins studied by geographical survey. In: Extended Abstr GEOMON Congr May 1987 (Moldan and Paces, eds) Prague, p 3

Mulder J, Van Breemen N, Eijck HC (1989) Depletion of soil aluminium by acid deposition and implications for acid neutralization. $\mathrm{Na}$ ture (Lond) 337, 247-249

Paces T (1985) Sources of acidification in Central Europe estimated from elemental bud- gets in small basins. Nature (Lond) 315,31 36

Pfans H, Beyschlag W (1992) Photosynthetic performance and nutrient status of Norway spruce at forest sites of the Ore Mountains (Erzgebirge). Trees (in press)

Probst A, Dambrine E, Viville D, Fritz B (1990) Influence of acid atmospheric inputs on surface water chemistry and mineral fluxes in a declining spruce stand within a small granitic catchment (Vosges massif - France). J Hydrol 2, 116, 101-124

Semb A, Dovland H (1987) Atmospheric deposition in Fenno-Scandia. In: Proc Int Symp Acidic Precipitation Muskoka (Martin H, ed) D Reidel, Dordrecht, 5-17

Vannier C (1992) Les modalités de la rétention du soufre dans les sols de deux bassins versants du Mont Lozère. Thèse, Univ Orléans, p 113 